\title{
The biomedical role of zinc in the functioning of the human organism
}

\begin{abstract}
Zinc is one of the most important microelements that can be found in the human organism. It is a component or an activator of various enzymes and takes part in more than 300 enzymatic reactions. It is present in all types of human tissue. About $90 \%$ of the general amount of zinc can be found in bones and muscles, $11 \%$ in liver and skin. $\mathrm{Zn}^{2+}$ ions are stable ions in biological environment and they do not participate in redox reactions that occur inside an organism. Assimilability of this element by living organisms is varied. It depends largely on the sort of food and interactions occurring between zinc and other elements. Zinc is an essential element for normal development and maintenance of human health.

The data presented in this article result from an overview of studies presented in literature published in the last five years concerning zinc transport mechanisms, the role of zinc in functioning of the human body, and also pathophysiological states caused by too low or excessive concentration of zinc in an organism.
\end{abstract}

Keywords: trace elements, zinc, functioning of the human organism.

DOI: $10.2478 /$ pjph-2014-0036

\section{INTRODUCTION}

Human organism consists of about sixty elements occurring in organic as well as inorganic forms. These elements occur in the form of various chemical compounds, and their role is essential in the normal development of an organism and maintaining health [1,2].

Zinc is a component of over 300 enzymes and even bigger number of proteins, which particularly emphasizes its indispensable role in human health. What is more, the processes such as: balanced metabolism of nucleic acids and proteins, growth, division and functionality of cells - require a definite amount of zinc in the organism $[3,4]$.

Human body contains 2-4 g of zinc, $90 \%$ of which occurs in muscles and bones. Other organs that contain trace amounts of this element are prostate, liver, digestive tract, kidneys, skin, lungs, brain, heart, and pancreas. The daily demand for this element is changeable and first of all depends on a person's age. For infants the demand is $3-5 \mathrm{mg}, 10 \mathrm{mg}$ for children and 10-15 mg for adults. On the cellular level, $40 \%$ of zinc is present in the nucleus, $50 \%$ in the cytoplasm, and the rest in the cell membrane.

The main source of zinc in organism is food that we provide, both, of animal and plant origin. Zinc, above all, is absorbed in duodenum, and excreted by digestive tract and kidneys [3,5].

Zinc ions are ingredients or activators of many enzymes, which take part in many, mainly metabolic, processes.
Activity of this bio element can be observed among others in such processes as mineralisation of bones, healing of injuries, correct secretion of insulin by pancreas, or maintaining the right level of vitamin A and cholesterol. The significant role of zinc was also observed in immunological processes. Moreover, zinc regulates blood pressure and pulse, contributes to the raised production of sperm, has a healing effect on the stomach-intestinal system, varicose veins, rheumatism and skin diseases [6]. Zinc deficiency, observed within human population in developing countries, triggers many disorders in functioning of the whole systems, as well as individual human organs [7]. Zinc is relatively little toxic for health, but its excess causes health disorders, such as vomiting, weakness, anaemia [5].

Information presented in the article results from the review of studies presented in the literature in the last five years, concerning transport mechanisms of zinc, the role of zinc in body`s metabolism, and also pathophysiological states caused by too low or excessive concentration of zinc in an organism.

\section{TRANSPORT MECHANISMS OF ZINC}

On the grounds of pleiotropic activity of zinc, shortage or excessive concentration of this element in cells can disturb functioning of almost every system within a human organism. Therefore, to maintain the correct concentration of zinc in the system, the human body has to create an active cell gradient of zinc. These gradients are generated by the mechanism of a circulating pump using ATP energy (hydrolysis). 
However, the activity of the mechanism has not been sufficiently examined in humans [8].

The studies already conducted suggest a possibility that zinc can be stored and released from intracellular vesicular compartments $[9,10]$.

Zinc homeostasis is precisely regulated by the digestive tract, which requires many coordinated transmitters. All zinc carriers belong to a big family of soluble carrier proteins, called SLC (Solute Carrier Family). This family is organized into 51 groups, counting in total over 300 carriers [11]. Two of the groups belonging to the SLC family, are responsible for transport of zinc in an organism, and they are the following: SLC30 (ZnT) and SLC39 (ZIP). ZnT carriers belong to the group SLC30, and they are responsible for the zinc leakage to cells, whereas SLC39 group contains ZIP carriers, which enable taking up zinc [12]. Up till now nine ZnT transporters and fifteen ZIP carriers have been identified in humans. ZnT and ZIP transporters have opposing roles in zinc homeostasis. ZnT carriers reduce intracellular zinc concentration by enabling zinc leakage from cells and zinc movement in intracellular vesicles. In turn, ZIP transporters increase intracellular zinc concentration by enabling zinc influx to cells and intracellular vesicular release of this element. Functions of many of these genes still need to be examined [13].

The loss of zinc takes place mainly in the intestine and may vary from 27 to $90 \mu \mathrm{mol}$ per day ( 24 hours). The loss of zinc through urine is comparably lower, and kidneys absorb filtrated zinc with an estimated loss of only 8-11 $\mu \mathrm{mol}$ per day. The loss of zinc occurs also through exfoliating of epithelium cells, through sweat, sperm, loss of hair, and also during women`s menses [13].

\section{ZINC INTERACTIONS WITH OTHER ELEMENTS}

Trace elements are an essential element for many metabolic changes occurring in a human organism. Both macroand microelements should appear in an organism in precisely defined concentrations. Both a shortage as well as excess of one of the elements can influence the concentration of the other elements. Bio elements can affect each other, thereby exerting an influence on their absorption, metabolism and utilization. The correlations existing among 13 elements, which include cobalt, copper, zinc, selenium, rubidium, rhodium, lead, cadmium, tungsten, mercury, titanium, palladium and platinum, were found in human blood. The elements can affect each other both in a synergic way, as well as in an antagonistic way [14,15].

The research carried out has shown that high concentration of calcium and magnesium in the space surrounding the cells is a certain obstacle in detecting the increase of the zinc level by the organism [16].

Zinc together with copper and selenium take part in many biochemical processes conditioning life. The most important is cellular respiration, cellular usage of oxygen, DNA and RNA replication, maintaining the integrity of the cell membrane, and also intercepting free radicals [17].

A research was also carried out [18], to evaluate the role of zinc in reducing biochemical changes triggered by aluminium taking place in a liver. The tests were carried out on rats, and the results confirmed the effectiveness of zinc therapy in relieving liver damages, caused by toxicity of aluminium. Nevertheless, similar tests have not been carried out on humans.

\section{SOURCES OF ZINC DEFICIENCY}

The causes of zinc deficiency in a human body can be various and may concern both the environment and the organism. In case of the environment, the deficiency can be caused by impoverished soil or by the type of the soil. Definitely more often the deficiencies result from improper nourishment, diet poor in mineral elements, and particularly low protein diet.

A vital role in making zinc deficiency is played by the reduction of its bioavailability, which can be caused by various factors, but first of all by digestive tract diseases, such as: coeliac disease, chronic enteritis, states after resection of stomach and intestines, Crohn syndrome, pancreas insufficiency, immaturity of the gastrointestinal tract. A diet rich in phytates, taking some medicines, and also stress favour reducing the bioavailability of this element [19].

\section{EFFECTS OF ZINC DEFICIENCY}

Effects of zinc deficiency can take a form of minor, short-lived symptoms, such as e.g. appetite disorders, smell and taste disorders, but they can also take a form of serious, incurable diseases such as diabetes, stroke, atherosclerosis or immunity disorders [4].

Disorders caused by zinc deficiency are manifested already before birth. Because of the fact that zinc is essential for normal development of brain, its deficiency can lead to developmental defects of the brain. Zinc deficiency during pregnancy can increase in a newborn baby the risk of developing behavioural and nervous disorders in future [20]. It has been also demonstrated that infections, especially pneumonia, that are a serious problem in developing countries, can develop more often in children with zinc deficiency [21].

The group of 60 obese Iranian children was also examined to check the influence of supplementing zinc preparations on metabolism and BMI (Body Mass Index) [22]. After completing the tests, in a group supplemented with zinc, a lower level of cholesterol, leptin, insulin resistance rates, reduction of body weight and lower BMI were found. It was also found that taking zinc can improve health and nutritional condition of children, and in this way contribute to the reduction of problems connected with insulin resistance [23].

The recent research suggests that supplementing zinc can significantly decrease the progress and intensity of diarrhoea episodes in children [24].

Zinc deficiency also strongly influences the organism of an adult human. In Pakistan, a group of women diagnosed with breast or ovarian cancer has been examined [25]. The results have shown a considerably lower level of zinc in women with diagnosed cancer.

Zinc deficiency can also cause neuropsychological and cognitive disorders [26]. Also the relation of zinc with Alzheimer's disease and other neurodegenerative diseases has been confirmed. It has been found out that zinc metabolism in a patient with Alzheimer's disease changes. [4,27]. Zinc deficiency can also cause the changes in behaviour, decrease 
efficiency of the learning process, deterioration of mental functions and susceptibility to convulsion attacks $[4,28]$.

Numerous clinical tests also suggest that zinc ion concentration in serum can be a marker of depression disorders [29].

The research shows that taking zinc has a positive effect on glycaemia control and positively influences lipid parameters, and moreover, lowers systolic and diastolic blood pressure [30].

Zinc deficiency also causes fertility disorders, manifesting as oligospermia, lower concentration of testosterone and testicular and ovary atrophy [31]. The effectiveness of zinc treatment therapy of many skin diseases, including seborrheic dermatitis, dandruff, psoriasis, androgenic alopecia or also chronic ulcerations and viral verruca has been confirmed [17].

Other pathological effects of zinc deficiency in organism are mainly the reduction of non-fat body mass, taste and smell impairment, inflammatory skin conditions (erythema), hair loss, reduction of cytokine production, antibodies and immunosuppression. Significant zinc deficiency causes also growth inhibition, liver and spleen enlargement (hepatosplenomegaly) and anorexia [19], as well as taste and appetite disorders [32]. The research shows that zinc deficiency causes inhibition of wound healing, reduction of thrombolytic aggregation, reduction of erythrocyte osmocity and greater bleeding tendency $[1,33]$.

\section{ZINC INFLUENCE ON THE IMMUNITY OF ORGA NISMS}

Zinc influences many aspects of the immunological system. Zinc deficiency causes thymic atrophy, disorders in thymus hormones, lymphopenia, the increase in the number of thymus hormones and their duration, dysfunction of immunological system cells and the impairment of its functioning [34].

Zinc is essential for normal development and functioning of cells responsible for inborn immunity, neutrophilia (neutrophilic granulocytes) and NK cells (Natural Killer). Zinc deficiency also influences the activity of macrophages, phagocytosis and production of cytokines. Zinc deficiency also influences negatively the growth and functioning of $\mathrm{T}$ and $\mathrm{B}$ lymphocytes [35].

Moreover, zinc deficiency may also result in a higher risk of infection with Type 1 Human Immunodeficiency Virus (HIV 1) as well as in higher mortality among the sick [36].

\section{FINAL REMARKS}

Zinc is an essential element for normal functioning of every human organism. Even small exceptions from the norm can cause disorders in the work of the whole system. It is necessary to eat reasonably and take the daily-recommended doses of zinc, most preferably along with food. In the times of widespread health problems, it is necessary to support health, but the most important is prevention. Thus, new studies, which help to demonstrate the role of trace elements in keeping good health, are still carried out.

\section{REFERENCES}

1. Ślęzak A, Zyska A. Rola jonów cynku w funkcjonowaniu organizmu człowieka. Żywienie Człow Metab. 2006;1:91-9.

2. Kabata-Pendias A, Pendias H. Biogeochemia pierwiastków śladowych. Warszawa: Wyd. Nauk. PWN;1999. p.145-56.

3. Plum L, Rink L, Haase H. The essential toxin: impact of zinc on human health. Int J Environ Res Public Health. 2010;7:1342-65.

4. Chasapis C, Loutsidou A, Spiliopoulou C, Stefanidou M. Zinc and human health: an update. Arch Toxicol. 2012;86:521-34.

5. Puzanowska-Tarasiewicz H, Kuźmicka L, Tarasiewicz M. Funkcje biologiczne wybranych pierwiastków. III. Cynk - składnik i aktywator enzymów. Pol Merk Lek. 2009;161:419-22.

6. Turek M, Łodyga-Chruścinska E. Zastosowanie w medycynie pochodnych indolu i jego kompleksów z biometalami. Food Chemistry and Biotechnol. 2008;72:73-88.

7. Prasad A. Impact of the Discovery of Human Zinc Deficiency on Health. J Am Coll Nutr. 2009;28:257-65.

8. Sekler I, Sensi S, Hershfinkel M, Silverman W. Mechanism and Regulation of Cellular Zinc Trasport. Mol Med. 2007;13:337-43.

9. Kambe T, Weaver B, Andrews G. The Genetics of Essential Metal Homeostasis During Development. Genesis. 2009;46:214-28.

10. Yamasaki S, Sakata-Sogawa K, Hasegawa A, et al. Zinc is a novel intracellular second messenger. J Cell Biol. 2007;177:637-45.

11. Hediger MA, Romero MF, Peng JB, et al. The ABCs of solutecarriers: physiological, pathological and therapeuticimplications of humanmembranetransport proteins. Introduction. Pflugers Arch. 2004;447:465-8.

12. Lichten L, Cousins RJ. Mammalian zinc transporters: nutritional and physiologic regulation. Annu Rev Nutr. 2009;29:153-76 .

13. Tuerk MJ, Fazel N. Zinc deficiency. Curr Opin Gastroenterol. 2009;25:136-43.

14. Ślęzak A, Zyska A. Cynk a choroby środowiskowe. In: A. Ślęzak, J. Jasik-Ślęzak (ed). Biomedyczne problemy zdrowia publicznego. Częstochowa: Wyższa Szkoła Hotelarstwa i Turystyki w Częstochowie; 2008. p. 137-47.

15. Barany E, Bergdahl I, Bratteby L, et al. Relationships between trace element concentrations in human blood and serum. Toxicology Letters. 2002;134:177-84.

16. Zhao J, Bertoglio B, Gee K, Kay A. The zinc indicator FluoZin-3 is not perturbed significantly by physiological levels of calcium or magnesium. Cell Calcium. 2008;44:422-6.

17. Bagherani N, Yaghoobi R, Omidian M. Hypothesis: zinc can be effective in treatment of vitiligo. Indian J Dermatol. 2011;56:480-4.

18. Bhasin P, Singla N, Dhawan DK. Protective role of zinc during aluminum-induced hepatotoxicity. Environ Toxicol. 2012;doi:10.1002/ tox.21760.

19. Gertig H, Przysławski J. Bromatologia. Zarys nauk o żywności i żywieniu. Warszawa: Wydawnictwo Lekarskie PZWL; 2007. p. 21621 .

20. Adamo AM, Oteiza PI. Zinc deficiency and neurodevelopment: the case of neurons. Biofactors. 2010;36:117-24.

21. Arıca S, Arıca V, Dag H, Kaya A, et al. Serum zinc levels in children of 0-24 months diagnosed with pneumonia admitted to our clinic. Int J Clin Exp Med. 2011;4:227-33.

22. Kelishadi R, Hashemipour M, Adeli K, et al. Effect of zinc supplementation on markers of insulin resistance, oxidative stress, and inflammation among prepubescent children with metabolic syndrome. Metab Syndr Relat Disord. 2010;8:505-10.

23. Ortega RM, Rodríguez-Rodríguez E, Aparicio A, et al. Poor zinc status is associated with increased risk of insulin resistance in Spanish children.Br J Nutr. 2012;107:398-404.

24. Bajait C, Thawani V. Role of zinc in pediatric diarrhea. Indian J Pharmacol. 2011;43:232-5.

25. Memon AU, Kazi TG, Afridi HI, et al. Evaluation of zinc status in whole blood and scalp hair of female cancer patients. Clin Chim Acta. 2007;379:66-70.

26. Takeda A, Tamano H, Ogawa T, Takada S, et al. Significance of serum glucocorticoid and chelatable zinc in depression and cognition in zinc deficiency. Behav Brain Res. 2012;226:259-64.

27. Wang CY, Wang T, Zheng W, et al. Zinc overload enhances APP cleavage and $\mathrm{Ab}$ deposition in the Alzheimer mouse brain. PLoS One. 2010;5:15349.

28. Amani R, Saeidi S, Nazari Z, Nematpour S. Correlationbetween dietary zinc intakes and its serum levels with depression scales in young female students. Biol Trace Elem Res. 2010;137:150-8. 
29. Siwek M, Dudek D, Zięba A, Nowak G. Stężenie cynku w surowicy jako obwodowy marker zaburzeń depresyjnych. Farmakoter Psychiatr Neurol. 2006;3:141-9.

30. Jayawardena R, Ranasinghe P, Galappatthy P, et al. Effects of zinc supplementation on diabetes mellitus: a systematic review and meta-analysis. Diabetol Metab Syndr. 2012;4:13.

31. Zdrojewicz Z, Wiśniewska A. Rola cynku w seksualności mężczyzn. Adv Clin Exp Med. 2005;14:1295-300.

32. Kawade R. Zinc status and its association with the health of adolescents: a review of studies in India. Glob Health Action. 2012, doi: 10.3402/gha. v5i0.7353.

33. Driscoll ER, Bettger WJ. The effect of dietary zinc deficiency in the rat on the lipid composition of the erythrocyte membrane Triton Shell. Lipids. 1993;27:972-7.

34. John E, Laskow T, Buchser W, et al. Zinc in innate and adaptive tumor immunity. J Transl Med. 2010;8:118.

35. Prasad A. Zinc and Human Health: Effect of Zinc on Immune Cells. Mol Med. 2008;14:353-7.

36. Afridi HI, Kazi TG, Kazi N, et al. Evaluation of zinc, copper and iron in biological samples (scalp hair, blood and urine) of tuberculosis and diarrhea male human immunodeficiency virus patients. Clin Lab. 2011;57:677-88.

\section{Corresponding author}

Aleksandra Zyska

36b Armii Krajowej Str., 42-200 Częstochowa, Poland

E-mail: aleksandrazyska@gmail.com 